\title{
BMJ Cigarette pack design and adolescent Open smoking susceptibility: a cross-sectional survey
}

\author{
Allison Ford, ${ }^{1,2}$ Anne Marie MacKintosh, ${ }^{1}$ Crawford Moodie, ${ }^{1}$ Sol Richardson, ${ }^{3}$ \\ Gerard Hastings ${ }^{1,2}$
}

To cite: Ford A,

Mackintosh AM, Moodie C, et al. Cigarette pack design and adolescent smoking susceptibility: a crosssectional survey. BMJ Open 2013:3:e003282.

doi:10.1136/bmjopen-2013003282

- Prepublication history for this paper is available online To view these files please visit the journal online (http://dx.doi.org/10.1136/ bmjopen-2013-003282)

Received 22 May 2013 Revised 16 July 2013 Accepted 2 August 2013
${ }^{1}$ Institute for Social Marketing, University of Stirling, Stirling, UK ${ }^{2}$ UK Centre for Tobacco Control Studies, University of Stirling, Stirling, UK ${ }^{3}$ Division of Epidemiology and Public Health, UK Centre for Tobacco Control Studies, University of Nottingham, Clinical Sciences Building, Nottingham City Hospital, Nottingham, UK

\section{Correspondence to} Allison Ford; a.j.ford@stir.ac.uk

\section{ABSTRACT}

Objectives: To compare adolescents' responses to three different styles of cigarette packaging: novelty (branded packs designed with a distinctive shape, opening style or bright colour), regular (branded pack with no special design features) and plain (brown pack with a standard shape and opening and all branding removed, aside from brand name).

Design: Cross-sectional in-home survey.

Setting: UK.

Participants: Random location quota sample of 1025 never smokers aged 11-16 years.

Main outcome measures: Susceptibility to smoking and composite measures of pack appraisal and pack receptivity derived from 11 survey items.

Results: Mean responses to the three pack types were negative for all survey items. However, 'novelty' packs were rated significantly less negatively than the 'regular' pack on most items, and the novelty and regular packs were rated less negatively than the 'plain' pack. For the novelty packs, logistic regressions, controlling for factors known to influence youth smoking, showed that susceptibility was associated with positive appraisal and also receptivity. For example, those receptive to the innovative Silk Cut Superslims pack were more than four times as likely to be susceptible to smoking than those not receptive to this pack (AOR=4.42, $95 \% \mathrm{Cl}$ 2.50 to $7.81, p<0.001$ ). For the regular pack, an association was found between positive appraisal and susceptibility but not with receptivity and susceptibility. There was no association with pack appraisal or receptivity for the plain pack.

Conclusions: Pack structure (shape and opening style) and colour are independently associated, not just with appreciation of and receptivity to the pack, but also with susceptibility to smoke. In other words, those who think most highly of novelty cigarette packaging are also the ones who indicate that they are most likely to go on to smoke. Plain packaging, in contrast, was found to directly reduce the appeal of smoking to adolescents.

\section{INTRODUCTION}

It is now firmly established that children are influenced by different modes of tobacco

\section{ARTICLE SUMMARY}

Strengths and limitations of this study

- The study allows an insight into how adolescents respond to novelty cigarette packaging that is available in the UK and other markets.

- This is the first study to examine how the attraction of cigarette packaging plays out in terms of smoking susceptibility using a sample size that supports robust statistical analysis.

- The cross-sectional nature of the survey does not enable causal relationships to be drawn about packaging and future smoking behaviour.

marketing. Observational and longitudinal studies have consistently demonstrated a robust association between exposure to, and appreciation of, tobacco advertising and promotions and smoking susceptibility-a predictor of future tobacco use ${ }^{1}$-among adolescents. ${ }^{2-4}$ Recently, a similar association has been found with point-of-sale (POS) displays. $^{5-7}$ This evidence has helped to inform tobacco control policy, resulting in advertising, promotions and POS display bans in the UK and elsewhere, to protect young people from the harmful influence of these types of marketing. Young people, however, continue to be exposed to tobacco packaging, a key promotional tool. ${ }^{8} 9$

Audits of recent trends in tobacco pack design have shown increasingly frequent redesign of packs and rising numbers of limited-edition packs and innovative pack shapes, textures and methods of openings. ${ }^{10-12}$ Tobacco industry analysts report new packaging developments, particularly those pertaining to new pack structures and technological printing advancements as 'ingenious innovations to keep the cigarette or cigar pack as an effective means, indeed the only means, to market the product ${ }^{13}$ while 'a more playful and easy approach to new designs, shapes and colours' means 'young consumers feel more catered for ${ }^{14}{ }^{14}$ Tobacco 
industry documents have revealed the appeal of innovative slim, oval, octagonal and booklet pack shapes to young people. ${ }^{15}$ Bright colours have also been used to communicate with this group. ${ }^{16}{ }^{17}$ While tobacco companies are careful to name young adults as a key target market, ${ }^{18-20}$ designers working alongside the tobacco industry have outlined the inevitable knock-on effect of tailoring designs for this audience. In 2007, for instance, an updated black and pink pack design for Camel No 9 was said to have a "Britney Spears Factor...If you want to attract younger women with your design, it will most likely also appeal to underage girls". ${ }^{17}$

The debate on plain packaging-which involves standardisation of pack size, shape, texture, method of opening, base colour and font-often focuses on the potential benefits to young people most at risk of smoking uptake. ${ }^{21}$ In England, 27\% of 11-15 year-olds have tried smoking. ${ }^{22}$ Experimentation has been shown to result in a loss of autonomy over tobacco use and can quickly lead to nicotine dependence. ${ }^{23} 24$ Plain packaging studies indirectly conclude that plain packaging is likely to reduce youth smoking uptake. ${ }^{25} 26 \mathrm{~A}$ recent study eliciting the opinions of tobacco control experts on the likely impact on smoking rates of plain packaging estimated that 2 years after its introduction there would be a three percentage point decline for children compared with a one percentage point decline for adults. ${ }^{27} \mathrm{~A}$ systematic review of plain packaging studies has outlined three main benefits of plain packaging. ${ }^{28}$ Within each of these areas, there is evidence of the benefit for children. Observational and experimental studies have shown that plain packaging can: reduce appeal, ${ }^{29-34}$ increase the salience of health warnings, ${ }^{25} 303335$ and reduce false beliefs about the harmfulness of tobacco products. ${ }^{32-34} 36$ However, little is known outside the tobacco industry about how consumers respond to novel packaging such as limited editions, ${ }^{37}$ or innovative pack shapes and openings, ${ }^{11} 343839$ and only two studies have focused on children: a small exploratory qualitative study ${ }^{11}$ and an internet survey which only assessed perceptions of plain packs. ${ }^{34}$ Furthermore, no association between pack innovation and susceptibility has been explored.

This study compares young people's responses to three different styles of cigarette packaging: novelty (branded packs with an innovative shape, style of opening or distinctive colour), regular (branded blue pack with a standard shape and opening) and plain (a brown pack with a standard shape and opening and all branding removed, aside from brand name). It also investigates any link between these responses and susceptibility. This study is particularly relevant, given that the debate on plain packaging continues. New Zealand has announced its intent to implement plain packaging and follow Australia's lead, where plain packaging was introduced in December 2012. In the UK, the Government announced in July 2013 that they will wait for evidence from Australia before making a final decision on plain packaging. ${ }^{40}$

\section{METHODS}

\section{Survey}

Data were collected between July and September 2011 as part of Wave six of the Youth Tobacco Policy Survey (YTPS). The YTPS is a long-running, repeat crosssectional study examining the impact of tobacco policies on young people. ${ }^{6}{ }^{41}{ }^{42}$ FACTS International, a market research company, recruited participants and conducted the survey. The fieldwork comprised in-home face-to-face interviews, accompanied by a self-completion questionnaire to gather more sensitive information on smoking behaviour. Ethical approval was obtained from the Institute for Sociomanagement ethics committee at the University of Stirling prior to beginning the study.

\section{Sampling strategy}

Random location quota sampling was used to generate a sample of 11-16 year-olds from households across the UK. Sampling involved a random selection of 92 electoral wards, stratified by Government Office Region and A Classification Of Residential Neighbourhoods (ACORN) classification (a geodemographic classification system that describes demographic and lifestyle profiles of small demographic areas) to ensure coverage of a range of geographic areas and sociodemographic backgrounds. Wards covering the islands, areas north of the Caledonian Canal, or those with fewer than three urban/suburban Enumeration Districts, were excluded from the sampling frame for cost and practicality reasons. In each selected ward, a quota sample, balanced across gender and age groups, was obtained. The narrow age group targeted in this survey and the random location quota methodology make this a difficult sample to locate, particularly as some of the randomly selected areas have a very low proportion of young people. Response rate details are not available as recording the number of contacts and participation and refusal rates becomes impractical when using this sampling methodology. A total sample of 1373 was achieved. Comparative census data for England and Wales in 2011 indicate that the achieved sample was in line with national figures for gender and age. ${ }^{43}$ In the 2011 census, $51 \%$ of $11-16$ year-olds were male and $49 \%$ were female. Thirty-two per cent of 11-16 year-olds were aged $11-12,33 \%$ were $13-14$ and $34 \%$ were $15-16$. This compares with the achieved sample, which was $50 \%$ male and $50 \%$ female, and comprised $33 \%$ of 11-12 year-olds, $35 \%$ of 13-14 year-olds, and 32\% of 15-16 year-olds. To examine the influence of pack design on susceptibility, this paper focuses exclusively on the 1025 never smokers in the sample. As the survey is part of a repeat crosssectional survey, taking several measures at different time points, sample size was determined on the basis of enabling within-survey subgroup analyses in addition to between-wave analyses. The survey aims for a minimum of 1150 per wave, with a corresponding sampling error of approximately $+/-3 \%$ and has the potential to detect changes in proportions of approximately $6 \%$ between 
waves with $80 \%$ power, $\alpha=0.05$. At each wave, the sample provides a subgroup sample of approximately 100 per age, within gender, to allow subgroup analyses.

\section{Development of the survey items and testing}

A number of stages between April and July 2011 informed the development and refinement of the 11 survey items. Initially, a set of eight exploratory qualitative focus groups with 15 year-olds generated understanding about how young people think about and respond to cigarette packaging. Ideas for survey items, question styles and visual prompts were examined in a further six focus groups, segmented by gender and age (11-12, 13-14 and 15-16 year-olds). A draft questionnaire was then piloted with 12 participants aged 1116 years. A professional interviewer administered the questionnaire, observed by a researcher. On completion of the questionnaire, the interviewer left the room to enable the researcher to conduct a cognitive interview to assess participant understanding, ease of responding, relevance of questions and ability to respond.

\section{Selection of packages}

Informed by the exploratory focus groups, five cigarette packs were selected to reflect a range of design features (figure 1). Pack A (Mayfair), a popular and familiar brand, represented an everyday pack without any notable design features, other than the blue colour, and was often referred to as 'standard'. It therefore provided the potential for use as a benchmark 'regular' pack against which other packs could be compared. Three packs (packs B-D) were selected to represent a range of 'novelty' packs with innovative and distinctive designs and a range of colours. Pack B (Silk Cut Superslims) was an innovative, smaller and slimmer than usual pack shape with elegant and feminine aspects. Pack C (Marlboro Bright Leaf) provided an example of innovative opening, resembling a flip-top cigarette lighter, more masculine features and dark colouring. Pack D (Pall Mall) represented a classic pack style but with a striking and unique bright pink colour. Pack E (a plain brown pack) represented a pack that was void of all design features.

\section{Procedure}

Parental permission and participant consent were secured prior to each interview. The interviews were conducted by trained professional researchers. Participants viewed one image, which displayed all five cigarette packs, and were asked to rate each pack on 11 items. The brand name of each pack was concealed in an attempt to reduce prior brand knowledge informing pack ratings. To maximise privacy, should anyone else be in the room where the interview was taking place, questions were displayed on showcards to enable participants to read responses from the card and give the number corresponding to their answer. Participants sealed their self-completed questionnaires in an envelope before handing back to the interviewer.

\section{Measures}

General information

Demographic information (age and gender) and smoking by parents, siblings and close friends was obtained. Socioeconomic status was determined by the occupation of the chief income earner within the participant's household.

\section{Smoking susceptibility}

Never smokers were categorised as those who had 'never tried smoking, not even a puff or two'. Susceptibility, defined by the absence of a firm decision not to smoke, ${ }^{1}$ was assessed across three items. Never smokers were classified as non-susceptible if they answered 'definitely not' to the questions 'If one of your friends offered you a cigarette, would you smoke it?' and 'Do you think you will smoke a cigarette at any time during the next year?' and to the likelihood that 'you will be smoking cigarettes at 18 years old'. Participants who answered anything other than 'definitely not' to any of the three items were classified as 'susceptible'.

\section{Pack responses}

Eleven items assessed young people's responses to packaging across the five different pack designs. Participants were asked: 'Can you tell me the number that best describes each pack?' and were assessed via scales: (1) Attractive/unattractive; (2) Eye-catching/not eyecatching; (3) Cool/not cool; (4) Not at all harmful/very harmful; (5) Fun/boring; (6) Worth looking at/not worth looking at; (7) Meant for someone like me/not meant for someone like me; (8) Grown-up/childish; (9) Puts me off smoking/tempts me to smoke; (10) I dislike this pack/I like this pack; and (11) I would not like to have this pack/I would like to have this pack. Responses were provided on five-point semantic scales (eg, 1='Attractive' to $5=$ ='Unattractive'). Prior to analysis, items (1-7) were reverse coded to make a low score (1) indicative of a negative rating and a high score (5) indicative of a positive pack rating.

\section{Statistical analysis}

The analysis focused on never smokers only. Paired ttests were used to produce mean scores of the 11 items for: (1) the 'regular' pack (Mayfair) relative to the mean scores for each of the three 'novelty' packs (Silk Cut Superslims, Marlboro Bright Leaf and Pall Mall) and (2) the plain pack relative to the mean scores of each of the other four packs. As the data resulting from the five point scales are ordinal, the Wilcoxon signed rank test, a non-parametric procedure suited to paired data, was used to test for significant differences between the ratings.

For each pack, a principal components analysis was conducted on the 11 items to explore the potential for reducing these 11 items to a smaller number of composite measures. Principal components were extracted using varimax rotation with the criteria of eigenvalues greater than 1 , consideration of the scree plot and component loadings $>$.44. Two composite measures were derived from 


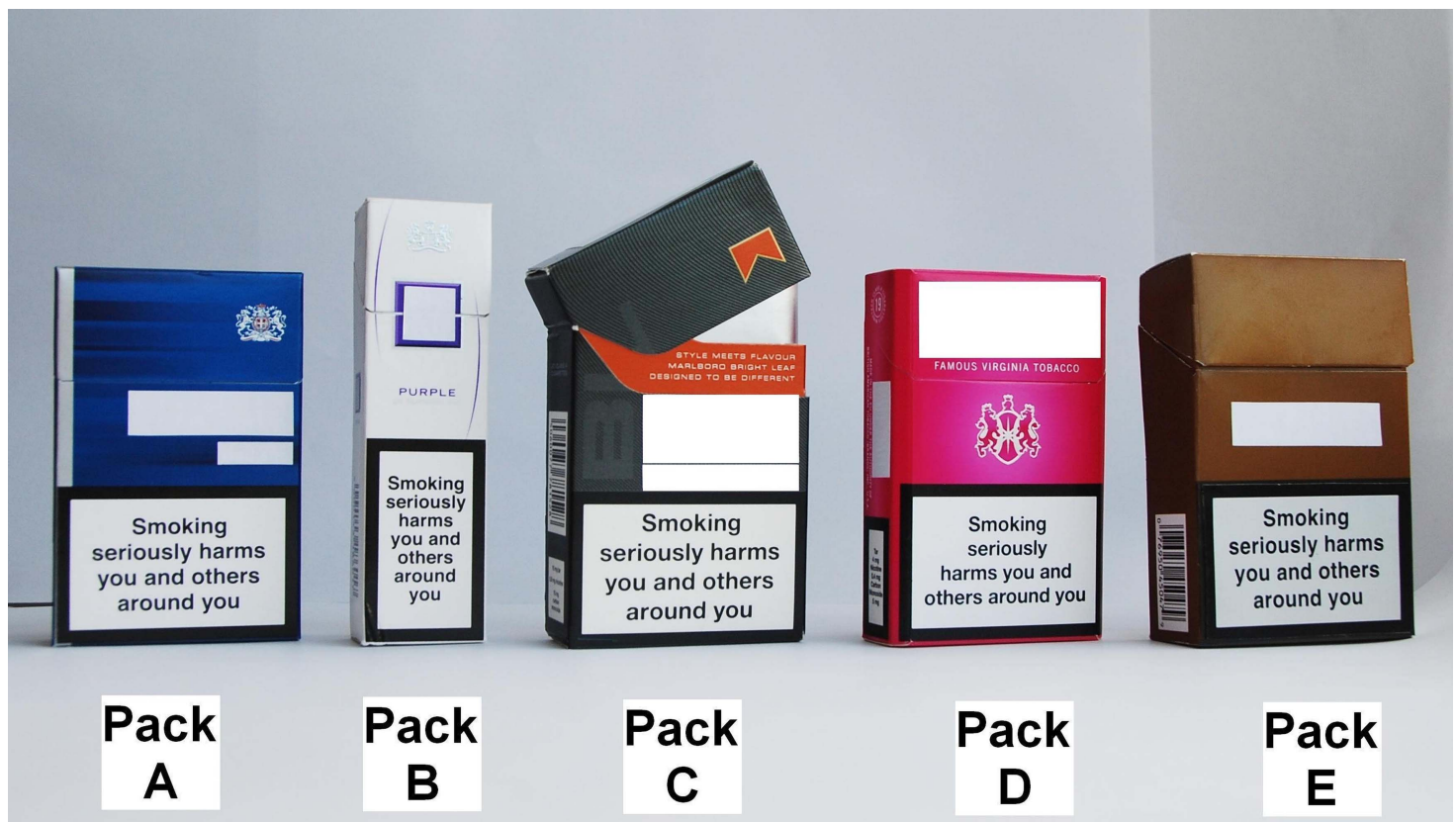

Figure 1 Visual stimuli shown to participants: Pack $A=$ 'regular' pack (Mayfair), Pack B='novelty' pack with innovative slim shape and size (Silk Cut Superslims), Pack C='novelty' pack with innovative method of opening (Marlboro Bright Leaf), Pack D='novelty' pack with distinctive and unique colour (Pall Mall), Pack E='plain' pack.

9 of the 11 items. Five items combined to form a composite pack appraisal measure (Cronbach's $\alpha>.8$ for each pack): (1) Unattractive/attractive; (2) Not eye-catching/ eye-catching; (3) Not cool/cool; (4) Boring/fun; (5) Not worth looking at/worth looking at. Four items combined to form a composite pack receptivity measure (Cronbach's $\alpha>.7$ for each pack): (6) Not meant for someone like me/ meant for someone like me; (7) Puts me off smoking/ tempts me to smoke; (8) I dislike this pack/I like this pack; (9) I would not like to have this pack/I would like to have this pack. Composite scores for each pack were derived by combining the pack ratings, with scores ranging from 5-25 for pack appraisal and 4-20 for pack receptivity. These scores were recoded into binary variables to enable a comparison of participants giving positive pack appraisal scores with those who gave non-positive appraisal scores and a comparison of those who were receptive with those not receptive. As 15 was the midpoint for the composite pack appraisal score, a score of 16 or over was considered reflective of an average positive response. Participants were classified as having a 'positive pack appraisal' (coded ' 1 ') if they scored 16 or more on the composite pack appraisal measure and a 'non-positive pack appraisal' (coded ' 0 ') if they scored 15 or less. As 12 was the midpoint for the composite pack receptivity score, a score of 13 or over was considered reflective of an average positive response. Participants were classified as 'receptive' (coded ' 1 ') to a pack if their composite receptivity score was 13 or more and 'not receptive' if their score was 12 or less (coded ' 0 ').

Analyses were carried out using generalised estimating equations (GEE) for binary outcomes with an exchangeable correlation structure in order to generate estimates of the likelihood of (1) positive appraisal and (2) receptivity for each pack. This method allowed us to account for the correlation between individual participants' scores when rating different packs. ${ }^{44}$ The quasi-information criterion (QIC) was used to select the most appropriate working correlation structure. In addition, we used cluster robust SEs to calculate variances. Finally, for each of the five packs, two hierarchical binary logistic regression models were constructed to examine whether any association existed between (1) positive pack appraisal and susceptibility and (2) receptivity to the pack and susceptibility. GEE and logistic regression models controlled for the potential influence of demographic and smoking-related factors identified in past research as influencing youth smoking. These independent variables were entered in blocks. In each model, block one controlled for whether the majority of close friends smoke, any siblings smoke and either parent smokes. Block two controlled for gender, socioeconomic group and age. The analyses using GEE were carried out in STATA V.11.2 for Windows, and SPSS V.19 was used for all other analyses.

\section{RESULTS}

\section{Sample}

A total of 1373 interviews were completed. Excluding cases that were missing for smoking status $(n=3), 75 \%$ $(\mathrm{n}=1025)$ were never smokers. Among these 1025 never smokers, $99 \% \quad(n=1019)$ provided information on smoking intentions, with $72 \% \quad(\mathrm{n}=733)$ classified as nonsusceptible and $28 \%(\mathrm{n}=286)$ as susceptible (table 1$)$. Comparative national figures for 11-15 year-olds indicate that smoking prevalence is in line with national data. In 


\begin{tabular}{cccc} 
Table 1 & Gender, age and social grade of never smokers \\
\hline \multicolumn{5}{c}{$\begin{array}{l}\text { Never } \\
\text { smoker } \\
\mathbf{n = 1 0 2 5}\end{array}$} & $\begin{array}{l}\text { Non-susceptible } \\
\mathbf{n}=\mathbf{7 3 3}\end{array}$ & $\begin{array}{l}\text { Susceptible } \\
\mathbf{n}=\mathbf{2 8 6} \\
\mathbf{N}(\%)\end{array}$ & $\mathbf{N}(\%)$ & $\mathbf{N}(\%)$ \\
\hline & $\mathbf{N}$ & \\
\hline Gender & & & $152(53)$ \\
Male & $528(51.5)$ & $373(51)$ & $134(47)$ \\
Female & $497(48.5)$ & $360(49)$ & $43(15)$ \\
Age & & & $56(20)$ \\
11 & $215(21)$ & $171(23)$ & $67(23)$ \\
12 & $204(20)$ & $146(20)$ & $55(19)$ \\
13 & $206(20)$ & $138(19)$ & $46(16)$ \\
14 & $176(17)$ & $119(16)$ & $19(7)$ \\
15 & $132(13)$ & $86(12)$ & $132(47)$ \\
16 & $92(9)$ & $73(10)$ & $151(53)$ \\
Social grade & & &
\end{tabular}

the 'Smoking, drinking and drug use among young people in England in 2011' survey, ${ }^{22} 75 \%$ of $11-15$ year-olds were never smokers and $25 \%$ were ever smokers. This compares with $79 \%$ never smokers and $21 \%$ ever smokers among 11 to 15 year-olds in this sample.

\section{Pack responses}

For the 11 survey items, the mean ratings of responses to all five cigarette packs were negative, with no mean scores on the positive end of the scale $(>3)$. While the mean scores for all packs were negative, mean scores for the three 'novelty' packs were significantly less negative than for the 'regular' Mayfair pack (Pack A; table 2). Mean scores for Silk Cut Superslims (Pack B), with its innovative slim shape and size, and the bright pink Pall Mall pack (Pack D) were significantly higher for all 11 items. Mean scores for the Marlboro Bright Leaf pack (Pack G) were significantly higher for 7 of the 11 items, except for 'meant for someone like me', 'childish' and 'tempts me to smoke'. This pack was also rated more harmful $(p=0.045)$ than the 'regular' Mayfair pack (Pack A).

By contrast, ratings for the plain pack (Pack E) were significantly more negative than for the 'regular' Mayfair pack (pack A) and each of the 'novelty' packs (Packs B-D). Mean scores for the plain pack ranged from 1.24 to 1.99 , which were significantly lower for all 11 items when compared with each of the other four packs (all $\mathrm{p}<0.01)$.

\section{Positive pack appraisal}

Eight per cent $(n=90)$ indicated positive appraisal of the 'regular' Mayfair pack. For the 'novelty' packs, 14\% $(\mathrm{n}=141)$ indicated positive appraisal for Marlboro Bright Leaf, $18 \% \quad(n=176)$ for Silk Cut Superslims and $21 \%$ $(n=209)$ for Pall Mall. Three percent $(n=34)$ had a positive appraisal score for the plain pack.
The results of the GEE analysis show that, after controlling for demographic and family and peer smoking variables, participants were more likely to give the brightly coloured Pall Mall (AOR=2.35, 95\% CI 1.96 to 2.81, $\mathrm{p}<0.001$, table 3), the Marlboro Bright Leaf $(\mathrm{AOR}=1.56,95 \%$ CI 1.29 to $1.88, \mathrm{p}<0.001)$ and the Silk Cut Superslims pack (AOR=1.94, 95\% CI 1.63 to 2.32, $\mathrm{p}<0.001)$ a positive appraisal score compared to the regular Mayfair pack. In addition, the plain pack was significantly less likely to receive a positive appraisal score $(\mathrm{AOR}=0.54,95 \%$ CI 0.43 to $0.67, \mathrm{p}<0.001)$. The final model also showed that positive pack appraisal among never smokers was more likely with increasing age but did not vary by gender or smoking-related variables.

\section{Positive pack receptivity}

Four per cent $(n=35)$ indicated being receptive to the 'regular' Mayfair pack. For the 'novelty' packs, 5\% $(n=50)$ were receptive to Marlboro Bright Leaf, 6\% $(\mathrm{n}=61)$ to Silk Cut Superslims and $7 \%(\mathrm{n}=71)$ to Pall Mall. For the plain pack, 3\% $(n=27)$ indicated being receptive to this pack.

The GEE analysis showed that participants were significantly more likely to be receptive to the three 'novelty' packs compared to the 'regular' Mayfair pack. Participants were over 1.6 times as likely to be receptive to the Pall Mall pack (AOR $=1.63,95 \%$ CI 1.31 to 2.02, $\mathrm{p}<0.001$, table 4 ), over 1.4 times as likely to be receptive to the Silk Cut Superslims pack (AOR=1.41, 95\% CI 1.13 to $1.76, \mathrm{p}=0.002$ ) and over 1.2 times as likely to be receptive to the Marlboro Bright Leaf pack (AOR=1.27, 95\% CI 1.03 to $1.58, \mathrm{p}=0.027)$. There was no significant difference between the plain pack and regular Mayfair pack in terms of the likelihood of being receptive $(\mathrm{AOR}=0.85$, $95 \%$ CI 0.68 to $1.07, \mathrm{p}=0.172$ ). Older participants were more likely to assign positive receptivity scores.

\section{Association between pack appraisal and susceptibility}

For each pack, logistic regression analysis, controlling for smoking-related and demographic variables, was conducted to examine the relationship between pack appraisal and susceptibility. For the 'regular' and each of the 'novelty' packs, positive appraisal was significantly associated with susceptibility. Those with a positive appraisal of the 'regular' Mayfair pack were twice as likely to be susceptible as those giving a non-positive appraisal $(\mathrm{AOR}=2.05,95 \%$ CI 1.29 to $3.25, \mathrm{p}=0.002)$. This was even more pronounced for each of the novelty packs. Participants with a positive appraisal of the smaller Silk Cut Superslims pack were more than twice as likely to be susceptible $(\mathrm{AOR}=2.20,95 \%$ CI 1.55 to $3.14, \mathrm{p}<0.001)$ and participants with a positive appraisal of the brightly coloured Pall Mall pack were almost 2.5 times as likely to be susceptible $(\mathrm{AOR}=2.45,95 \%$ CI 1.76 to $3.43, \mathrm{p}<0.001)$. This association was strongest for the innovative Marlboro Bright Leaf pack, whereby susceptibility was 2.51 times higher for participants expressing a positive appraisal of the pack $(\mathrm{AOR}=2.51,95 \%$ CI 1.71 
Table 2 Mean ratings on response to 'regular' pack (Mayfair) versus 'novelty' and 'plain' packs

\begin{tabular}{|c|c|c|c|c|c|c|c|c|c|c|c|c|}
\hline & \multicolumn{3}{|c|}{$\begin{array}{l}\text { Mayfair vs. novelty pack } \\
\text { B (Silk Cut Superslims) } \\
\end{array}$} & \multicolumn{3}{|c|}{$\begin{array}{l}\text { Mayfair vs. novelty pack } \\
\text { C (Marlboro Bright } \\
\text { Leaf) }\end{array}$} & \multicolumn{3}{|c|}{$\begin{array}{l}\text { Mayfair vs. novelty pack } \\
\text { D (Pall Mall) }\end{array}$} & \multicolumn{3}{|c|}{ Mayfair vs. plain pack } \\
\hline & $\begin{array}{l}\text { M'fair } \\
\text { Mean } \\
\text { SD } \\
\end{array}$ & $\begin{array}{l}\text { Silk Cut } \\
\text { Mean } \\
\text { SD } \\
\end{array}$ & p Value* & $\begin{array}{l}\text { M'fair } \\
\text { Mean } \\
\text { SD } \\
\end{array}$ & $\begin{array}{l}\text { M'boro } \\
\text { Mean } \\
\text { SD }\end{array}$ & p Value & $\begin{array}{l}\text { M'fair } \\
\text { Mean } \\
\text { SD } \\
\end{array}$ & $\begin{array}{l}\text { Pall Mall } \\
\text { Mean } \\
\text { SD } \\
\end{array}$ & p Value & $\begin{array}{l}\text { M'fair } \\
\text { Mean } \\
\text { SD } \\
\end{array}$ & $\begin{array}{l}\text { Plain } \\
\text { Mean } \\
\text { SD } \\
\end{array}$ & p Value \\
\hline \multicolumn{13}{|l|}{ Individual items } \\
\hline Unattractive (1)/attractive (5) & $\begin{array}{l}1.92 \\
1.11\end{array}$ & $\begin{array}{l}2.13 \\
1.56\end{array}$ & $<0.001$ & $\begin{array}{l}1.92 \\
1.11\end{array}$ & $\begin{array}{l}2.06 \\
1.23\end{array}$ & $<0.001$ & $\begin{array}{l}1.92 \\
1.11\end{array}$ & $\begin{array}{l}2.32 \\
1.38\end{array}$ & $<0.001$ & $\begin{array}{l}1.91 \\
1.11\end{array}$ & $\begin{array}{l}1.48 \\
0.94\end{array}$ & $<0.001$ \\
\hline Not eye-catching (1) /eye-catching (5) & $\begin{array}{l}2.04 \\
1.27\end{array}$ & $\begin{array}{l}2.38 \\
1.41\end{array}$ & $<0.001$ & $\begin{array}{l}2.04 \\
1.27\end{array}$ & $\begin{array}{l}2.23 \\
1.35\end{array}$ & $<0.001$ & $\begin{array}{l}2.04 \\
1.27\end{array}$ & $\begin{array}{l}2.72 \\
1.53\end{array}$ & $<0.001$ & $\begin{array}{l}2.03 \\
1.26\end{array}$ & $\begin{array}{l}1.56 \\
1.01\end{array}$ & $<0.001$ \\
\hline Not cool (1) /cool (5) & $\begin{array}{l}1.60 \\
1.04\end{array}$ & $\begin{array}{l}1.85 \\
1.22\end{array}$ & $<0.001$ & $\begin{array}{l}1.60 \\
1.04\end{array}$ & $\begin{array}{l}1.82 \\
1.22\end{array}$ & $<0.001$ & $\begin{array}{l}1.60 \\
1.04\end{array}$ & $\begin{array}{l}1.83 \\
1.22\end{array}$ & $<0.001$ & $\begin{array}{l}1.60 \\
1.04\end{array}$ & $\begin{array}{l}1.34 \\
0.80\end{array}$ & $<0.001$ \\
\hline Very harmful (1)/not at all harmful(5) & $\begin{array}{l}1.62 \\
1.04\end{array}$ & $\begin{array}{l}1.72 \\
1.14\end{array}$ & $<0.001$ & $\begin{array}{l}1.62 \\
1.04\end{array}$ & $\begin{array}{l}1.58 \\
1.02\end{array}$ & 0.045 & $\begin{array}{l}1.62 \\
1.04\end{array}$ & $\begin{array}{l}1.69 \\
1.11\end{array}$ & $<0.001$ & $\begin{array}{l}1.62 \\
1.04\end{array}$ & $\begin{array}{l}1.50 \\
0.98\end{array}$ & $<0.001$ \\
\hline Boring (1)/fun (5) & $\begin{array}{l}1.69 \\
0.98\end{array}$ & $\begin{array}{l}1.97 \\
1.21\end{array}$ & $<0.001$ & $\begin{array}{l}1.69 \\
0.98\end{array}$ & $\begin{array}{l}1.85 \\
1.14\end{array}$ & $<0.001$ & $\begin{array}{l}1.69 \\
0.98\end{array}$ & $\begin{array}{l}2.02 \\
1.26\end{array}$ & $<0.001$ & $\begin{array}{l}1.68 \\
0.98\end{array}$ & $\begin{array}{l}1.34 \\
0.74\end{array}$ & $<0.001$ \\
\hline Not worth looking at (1)/worth looking at (5) & $\begin{array}{l}1.55 \\
0.98\end{array}$ & $\begin{array}{l}1.74 \\
1.15\end{array}$ & $<0.001$ & $\begin{array}{l}1.55 \\
0.98\end{array}$ & $\begin{array}{l}1.67 \\
1.09\end{array}$ & $<0.001$ & $\begin{array}{l}1.54 \\
0.98\end{array}$ & $\begin{array}{l}1.74 \\
1.13\end{array}$ & $<0.001$ & $\begin{array}{l}1.55 \\
0.98\end{array}$ & $\begin{array}{l}1.31 \\
0.76\end{array}$ & $<0.001$ \\
\hline $\begin{array}{l}\text { Not meant for someone like me (1)meant or someone } \\
\text { like me (5) }\end{array}$ & $\begin{array}{l}1.34 \\
0.77\end{array}$ & 1.42 & $<0.001$ & $\begin{array}{l}1.34 \\
0.76\end{array}$ & 1.34 & 0.658 & 1.34 & 1.44 & $<0.001$ & 1.34 & $\begin{array}{l}1.24 \\
0.68\end{array}$ & $<0.001$ \\
\hline Grown-up (1)/childish (5) & $\begin{array}{l}2.06 \\
1.31\end{array}$ & $\begin{array}{l}2.23 \\
1.37\end{array}$ & $<0.001$ & $\begin{array}{l}2.06 \\
1.31\end{array}$ & $\begin{array}{l}2.08 \\
1.31\end{array}$ & 0.596 & $\begin{array}{l}2.06 \\
1.31\end{array}$ & $\begin{array}{l}2.39 \\
1.39\end{array}$ & $<0.001$ & $\begin{array}{l}2.06 \\
1.31\end{array}$ & $\begin{array}{l}1.99 \\
1.32\end{array}$ & 0.006 \\
\hline Puts me off (1)/tempts me to smoke (5) & $\begin{array}{l}1.62 \\
1.06\end{array}$ & $\begin{array}{l}1.67 \\
1.08\end{array}$ & 0.002 & $\begin{array}{l}1.62 \\
1.06\end{array}$ & $\begin{array}{l}1.63 \\
1.08\end{array}$ & 0.678 & $\begin{array}{l}1.62 \\
1.06\end{array}$ & $\begin{array}{l}1.67 \\
1.10\end{array}$ & 0.001 & $\begin{array}{l}1.62 \\
1.06\end{array}$ & $\begin{array}{l}1.48 \\
1.01\end{array}$ & $<0.001$ \\
\hline I dislike this pack (1)/I like this pack (5) & $\begin{array}{l}1.81 \\
1.14\end{array}$ & $\begin{array}{l}2.10 \\
1.29\end{array}$ & $<0.001$ & $\begin{array}{l}1.81 \\
1.14\end{array}$ & $\begin{array}{l}1.97 \\
1.24\end{array}$ & $<0.001$ & $\begin{array}{l}1.81 \\
1.14\end{array}$ & $\begin{array}{l}2.17 \\
1.36\end{array}$ & $<0.001$ & $\begin{array}{l}1.82 \\
1.14\end{array}$ & $\begin{array}{l}1.51 \\
0.98\end{array}$ & $<0.001$ \\
\hline $\begin{array}{l}\text { I would not like to have this pack (1)/I would like to } \\
\text { have this pack (5) } \\
\text { Composite Measures }\end{array}$ & 0.92 & 1.51 & $<0.001$ & $\begin{array}{l}1.43 \\
0.92\end{array}$ & 1.50 & $<0.001$ & $\begin{array}{l}1.43 \\
0.92\end{array}$ & $\begin{array}{l}1.54 \\
1.05\end{array}$ & $<0.001$ & $\begin{array}{l}1.43 \\
0.92\end{array}$ & $\begin{array}{l}1.33 \\
0.87\end{array}$ & $<0.001$ \\
\hline Pack appraisal & $\begin{array}{l}8.81 \\
4.22\end{array}$ & $\begin{array}{r}10.09 \\
5.05\end{array}$ & $<0.001$ & $\begin{array}{l}8.81 \\
4.21\end{array}$ & $\begin{array}{l}9.64 \\
4.80\end{array}$ & $<0.001$ & $\begin{array}{l}8.80 \\
4.21\end{array}$ & $\begin{array}{r}10.66 \\
5.18\end{array}$ & $<0.001$ & $\begin{array}{l}8.80 \\
4.21\end{array}$ & $\begin{array}{l}7.03 \\
3.29\end{array}$ & $<0.001$ \\
\hline Pack receptivity & $\begin{array}{l}6.20 \\
2.84 \\
\end{array}$ & $\begin{array}{l}6.68 \\
3.07\end{array}$ & $<0.001$ & $\begin{array}{l}6.19 \\
2.83 \\
\end{array}$ & $\begin{array}{l}6.44 \\
3.02 \\
\end{array}$ & $<0.001$ & $\begin{array}{l}6.20 \\
2.84 \\
\end{array}$ & $\begin{array}{l}6.83 \\
3.21 \\
\end{array}$ & $<0.001$ & $\begin{array}{l}6.20 \\
2.84 \\
\end{array}$ & $\begin{array}{l}5.57 \\
2.53\end{array}$ & $<0.001$ \\
\hline
\end{tabular}

*Wilcoxon signed rank test for significant differences. 
Table 3 General estimating equations for binary outcomes: pack appraisal

\begin{tabular}{|c|c|c|c|c|c|}
\hline \multirow{2}{*}{$\begin{array}{l}\text { Dependent variable: pack appraisal } \\
1=\text { Positive apprasial }(\text { score } \geq 16) \\
0=\text { Negative appraisal }(\text { score }<16)\end{array}$} & \multirow[b]{2}{*}{$n=1001$} & \multirow[b]{2}{*}{ AOR } & \multicolumn{2}{|l|}{$95 \% \mathrm{Cl}$} & \multirow[b]{2}{*}{ p Value } \\
\hline & & & Lower & Upper & \\
\hline \multicolumn{6}{|l|}{ Block 1} \\
\hline \multicolumn{6}{|l|}{ Close friends smoking } \\
\hline Most do not smoke & 842 & 1.00 & & & \\
\hline Majority smoke & 47 & 1.02 & 0.56 & 1.89 & 0.939 \\
\hline Do not know/not stated & 112 & 1.11 & 0.75 & 1.63 & 0.603 \\
\hline \multicolumn{6}{|l|}{ Sibling smoking } \\
\hline No siblings smoke & 836 & 1.00 & & & \\
\hline Any siblings smoke & 137 & 0.82 & 0.55 & 1.22 & 0.318 \\
\hline Do not know/not stated & 28 & 0.68 & 0.30 & 1.55 & 0.360 \\
\hline \multicolumn{6}{|l|}{ Parental smoking } \\
\hline Neither parent smokes & 567 & 1.00 & & & \\
\hline Either parent smokes & 375 & 0.90 & 0.68 & 1.19 & 0.453 \\
\hline Not sure/not stated/no mum/dad & 59 & 1.25 & 0.75 & 2.09 & 0.386 \\
\hline \multicolumn{6}{|l|}{ Block 2} \\
\hline \multicolumn{6}{|l|}{ Gender } \\
\hline Male & 515 & 1.00 & & & \\
\hline Female & 486 & 1.06 & 0.82 & 1.36 & 0.656 \\
\hline \multicolumn{6}{|l|}{ Socioeconomic group } \\
\hline $\mathrm{ABC} 1$ & 461 & 1.00 & & & \\
\hline C2DE & 540 & 0.95 & 0.73 & 1.24 & 0.713 \\
\hline Age & 1001 & 1.22 & 1.13 & 1.32 & $<0.001$ \\
\hline \multicolumn{6}{|l|}{ Block 3} \\
\hline \multicolumn{6}{|l|}{ Pack } \\
\hline Mayfair & 1001 & 1.00 & & & \\
\hline Silk cut superslims & 1001 & 1.94 & 1.63 & 2.32 & $<0.001$ \\
\hline Marlboro bright leaf & 1001 & 1.56 & 1.29 & 1.88 & $<0.001$ \\
\hline Pall mall & 1001 & 2.35 & 1.96 & 2.81 & $<0.001$ \\
\hline Plain & 1001 & 0.54 & 0.43 & 0.67 & $<0.001$ \\
\hline \multirow[t]{2}{*}{ Model summary at each block } & \multicolumn{4}{|c|}{ Test of model coefficients } & QIC \\
\hline & Wald $\chi^{2}$ & df & $\mathrm{p}$ Value & & \\
\hline Block 1 & 4.99 & 6 & 0.546 & & 7080.07 \\
\hline Block 2 & 17.03 & 3 & $<0.001$ & & 6808.46 \\
\hline Block 3 & 178.59 & 4 & $<0.001$ & & 6772.13 \\
\hline Final model & 183.19 & 13 & $<0.001$ & & 6579.37 \\
\hline
\end{tabular}

to $3.67, \mathrm{p}<0.001$, table 5). There was no association between positive appraisal of the plain pack and susceptibility ( $\mathrm{AOR}=1.04,95 \%$ CI 0.48 to $2.26, \mathrm{p}=0.914)$.

\section{Association between pack receptivity and susceptibility}

For each pack, logistic regression analysis, controlling for demographic and smoking-related variables, was used to examine the relationship between pack receptivity and smoking susceptibility. Receptivity to the three 'novelty' pack styles was positively associated with susceptibility. Participants receptive to the Pall Mall pack were more than 3.5 times as likely to be susceptible $(\mathrm{AOR}=3.69$, $95 \%$ CI 2.21 to $6.19, \mathrm{p}<0.001)$ and those receptive to the Marlboro Bright Leaf pack almost 2.5 times as likely to be susceptible (AOR=2.42, 95\% CI 1.32 to 4.44, $\mathrm{p}=0.004)$, compared to participants not receptive to these packs. Participants receptive to the Silk Cut Superslims pack were more than four times as likely to be susceptible compared with those who were not receptive $(\mathrm{AOR}=4.42,95 \%$ CI 2.50 to $7.81, \mathrm{p}<0.001$, table 6$)$. No significant association was observed between susceptibility and receptivity to the 'regular' Mayfair pack (AOR=1.97, 95\% CI 0.96 to $4.03, \mathrm{p}=0.064$ ) or the plain pack $(\mathrm{AOR}=0.92,95 \%$ CI 0.38 to $2.27, \mathrm{p}=0.863)$.

\section{DISCUSSION}

This study examines never smokers' responses to three different styles of cigarette packaging: 'novelty' (branded packs designed to incorporate unique and distinctive features), 'regular' (branded packs with no special design features) and 'plain' (a brown pack with a standard shape and opening and all branding removed, aside from brand name). The mean ratings of responses to all three types of packs were negative across all survey items. However, ratings of 'novelty' packs, with a distinctive shape, opening style or bright colour, were significantly 
Table 4 General estimating equations for binary outcomes: receptivity

\begin{tabular}{|c|c|c|c|c|c|}
\hline \multirow{2}{*}{$\begin{array}{l}\text { Dependent variable: pack receptivity } \\
1=\text { Receptive }(\text { score } \geq 13) \\
0=\text { Not receptive }(\text { score }<13)\end{array}$} & \multirow[b]{2}{*}{$n=1001$} & \multirow[b]{2}{*}{ AOR } & \multicolumn{2}{|l|}{$95 \% \mathrm{Cl}$} & \multirow[b]{2}{*}{ p Value } \\
\hline & & & Lower & Upper & \\
\hline \multicolumn{6}{|l|}{ Block 1} \\
\hline \multicolumn{6}{|l|}{ Close friends smoking } \\
\hline Most do not smoke & 842 & 1.00 & & & \\
\hline Majority smoke & 47 & 1.93 & 0.99 & 3.77 & 0.054 \\
\hline Do not know/not stated & 112 & 1.22 & 0.70 & 2.14 & 0.485 \\
\hline \multicolumn{6}{|l|}{ Sibling smoking } \\
\hline No siblings smoke & 836 & 1.00 & & & \\
\hline Any siblings smoke & 137 & 1.12 & 0.65 & 1.92 & 0.690 \\
\hline Do not know/not stated & 28 & 0.12 & 0.02 & 0.84 & 0.033 \\
\hline \multicolumn{6}{|l|}{ Parental smoking } \\
\hline Neither parent smokes & 567 & 1.00 & & & \\
\hline Either parent smokes & 375 & 0.84 & 0.57 & 1.24 & 0.389 \\
\hline Not sure/not stated/no mum/dad & 59 & 0.75 & 0.35 & 1.63 & 0.472 \\
\hline \multicolumn{6}{|l|}{ Block 2} \\
\hline \multicolumn{6}{|l|}{ Gender } \\
\hline Male & 515 & 1.00 & & & \\
\hline Female & 486 & 0.86 & 0.60 & 1.25 & 0.433 \\
\hline \multicolumn{6}{|l|}{ Socioeconomic group } \\
\hline $\mathrm{ABC} 1$ & 461 & 1.00 & & & \\
\hline C2DE & 540 & 1.25 & 0.85 & 1.84 & 0.249 \\
\hline Age & 1001 & 1.21 & 1.08 & 1.37 & 0.002 \\
\hline \multicolumn{6}{|l|}{ Block 3} \\
\hline \multicolumn{6}{|l|}{ Pack } \\
\hline Mayfair & 1001 & 1.00 & & & \\
\hline Silk cut superslims & 1001 & 1.41 & 1.13 & 1.76 & 0.002 \\
\hline Marlboro bright leaf & 1001 & 1.27 & 1.03 & 1.58 & 0.027 \\
\hline Pall mall & 1001 & 1.63 & 1.31 & 2.02 & $<0.001$ \\
\hline Plain & & 0.85 & 0.68 & 1.07 & 0.172 \\
\hline \multirow[t]{2}{*}{ Model summary at each block } & \multicolumn{4}{|c|}{ Test of model coefficients } & QIC \\
\hline & Wald $\chi^{2}$ & df & $\mathrm{p}$ Value & & \\
\hline Block 1 & 12.68 & 6 & 0.049 & & 5148.46 \\
\hline Block 2 & 12.50 & 3 & 0.006 & & 5099.46 \\
\hline Block 3 & 38.70 & 4 & $<0.001$ & & 5317.10 \\
\hline Final model & 57.40 & 13 & $<0.001$ & & 4894.45 \\
\hline
\end{tabular}

less negative than the ratings of the 'regular' pack on most items and both styles of packaging were rated less negatively than the 'plain' pack on all items. For example, the bright pink Pall Mall and tall and narrow Silk Cut Superslims packs were rated higher than a regular blue king size pack (Mayfair) on all survey items. The Marlboro Bright Leaf pack, with its unique 'Zippo' style opening was rated higher than Mayfair on most items. General estimating questions for binary outcomes also indicated that positive pack appraisal and receptivity to the pack were more likely with the three 'novelty' packs relative to the 'regular' Mayfair pack. Positive appraisal was less likely with the plain pack compared with the 'regular' pack. For the three distinctive styles, logistic regressions, controlling for factors known to influence youth smoking, showed that susceptibility was associated with positive appraisal and also receptivity. For example, those receptive to the innovative Silk Cut Superslims pack were more than four times as likely to be susceptible to smoking, compared with participants who were not receptive to this pack. For the regular pack, an association was found between positive appraisal and susceptibility but not with receptivity and susceptibility. For the plain pack, no association was found between pack appraisal or receptivity and susceptibility.

The study benefits from a national sample of adolescents. Given that gender, age and smoking prevalence are in line with national data, ${ }^{22} 43$ the sample is likely to be representative of the wider adolescent population in the UK. In addition, the main outcome measure of susceptibility is a well validated measure of smoking intentions. ${ }^{1}$ There are, however, a number of potential limitations. The cross-sectional nature of the survey does not enable causal relationships to be drawn about packaging and future smoking behaviour. The interviews were conducted in-home, where a family member may be present. In this instance, participants may be worried about having positive perceptions surrounding tobacco and socially desirable responses may have provided 
Table 5 Logistic regression of association between susceptibility to smoke and pack appraisal of the 'novelty' Marlboro Bright Leaf pack

\begin{tabular}{|c|c|c|c|c|c|}
\hline \multirow[b]{2}{*}{ Dependent variable: susceptibility, $1=$ Susceptible, $0=$ Non-susceptible } & \multirow[b]{2}{*}{$\mathrm{n}=968$} & \multirow[b]{2}{*}{ AOR } & \multicolumn{2}{|l|}{$95 \% \mathrm{Cl}$} & \multirow[b]{2}{*}{ p Value } \\
\hline & & & Lower & Upper & \\
\hline \multicolumn{6}{|l|}{ Block 1} \\
\hline \multicolumn{6}{|l|}{ Close friends smoking } \\
\hline Most do not smoke & 815 & 1.00 & & & 0.401 \\
\hline Majority smoke & 46 & 1.48 & 0.77 & 2.83 & 0.240 \\
\hline Do not know/not stated & 107 & 1.19 & 0.76 & 1.88 & 0.444 \\
\hline \multicolumn{6}{|l|}{ Sibling smoking } \\
\hline No siblings smoke & 807 & 1.00 & & & $<0.001$ \\
\hline Any siblings smoke & 134 & 2.39 & 1.60 & 3.57 & $<0.001$ \\
\hline Do not know/not stated & 27 & 1.99 & 0.89 & 4.44 & 0.093 \\
\hline \multicolumn{6}{|l|}{ Parental smoking } \\
\hline Neither parent smokes & 544 & 1.00 & & & 0.054 \\
\hline Either parent smokes & 367 & 1.89 & 1.06 & 3.39 & 0.032 \\
\hline Not sure/not stated/no mum/dad & 57 & 1.29 & 0.94 & 1.78 & 0.113 \\
\hline \multicolumn{6}{|l|}{ Block 2} \\
\hline \multicolumn{6}{|l|}{ Gender } \\
\hline Male & 497 & 1.00 & & & \\
\hline Female & 471 & 0.86 & 0.64 & 1.15 & 0.301 \\
\hline \multicolumn{6}{|l|}{ Socioeconomic group } \\
\hline$A B C 1$ & 448 & 1.00 & & & \\
\hline C2DE & 520 & 0.79 & 0.59 & 1.06 & 0.120 \\
\hline Age & 968 & 1.06 & 0.97 & 1.16 & 0.223 \\
\hline \multicolumn{6}{|l|}{ Block 3} \\
\hline \multicolumn{6}{|l|}{ Packaging appraisal of Marlboro Bright Leaf } \\
\hline Not positive appraisal & 828 & 1.00 & & & \\
\hline Positive appraisal & 140 & 2.51 & 1.71 & 3.67 & $<0.001$ \\
\hline Model summary at each block & \multicolumn{3}{|c|}{ Test of model coefficients } & \multirow{2}{*}{\multicolumn{2}{|c|}{ Nagelkerke R }} \\
\hline & & df & $\mathrm{p}$ Value & & \\
\hline Block 1 & 24.761 & 6 & $<0.001$ & & 0.036 \\
\hline Block 2 & 7.819 & 3 & 0.050 & & 0.047 \\
\hline Block 3 & 21.700 & 1 & $<0.001$ & & 0.078 \\
\hline Final model & 54.279 & 10 & $<0.001$ & & 0.078 \\
\hline
\end{tabular}

lower ratings. Finally, despite concealing brand names and identifiers, prior brand knowledge may have influenced pack responses, especially for the 'regular' Mayfair pack, which is a common youth brand.

Despite these limitations, the findings are consistent with the growing body of evidence that on-pack branding-especially when accompanied by innovative and distinctive design features-makes cigarette packs more appealing to young people and removing these does the reverse. ${ }^{11}$ 29-34 It supports previous research, which has found 'slim' packs particularly appealing to young females ${ }^{45}$ and innovative methods of openings to young adults ${ }^{38}$ and adolescents. ${ }^{11}$ This replicates the tobacco industry research findings that young people are attracted to something 'new'. ${ }^{46} 47$ The study adds to this literature by demonstrating a significant association between novel and distinctive pack designs and susceptibility to smoking in the future. It also provides a measure for pack appraisal and receptivity, both of which were independently associated with susceptibility.

This study provides the first direct evidence that the attractiveness of cigarette packaging is associated with susceptibility to smoke. Differences among the packaging styles highlight the influence of innovative and unique branding elements on adolescents' future smoking intentions. Despite the marketing restrictions on advertising and POS displays, children continue to be influenced by tobacco companies through packaging design. The study helps explain why policymakers are keen to control this powerful type of marketing and why a number of countries are considering following Australia's lead and introducing plain packaging. Furthermore, it suggests that the European Commission's proposal to update the Tobacco Products Directive and include a ban on slim 'lipstick type' cigarette packs, to prevent such packs misleading consumers in respect to harm, appears warranted. ${ }^{48} 49$ 
Table 6 Logistic regression of association between susceptibility to smoke and packaging receptivity to Silk Cut Superslims

\begin{tabular}{|c|c|c|c|c|c|}
\hline \multirow[b]{2}{*}{ Dependent variable: susceptibility, $1=$ Susceptible, $0=$ Non-susceptible } & \multirow[b]{2}{*}{$\mathrm{n}=970$} & \multirow[b]{2}{*}{ AOR } & \multicolumn{2}{|l|}{$95 \% \mathrm{Cl}$} & \multirow[b]{2}{*}{ p Value } \\
\hline & & & Lower & Upper & \\
\hline \multicolumn{6}{|l|}{ Block 1} \\
\hline \multicolumn{6}{|l|}{ Close friends smoking } \\
\hline Most do not smoke & 814 & 1.00 & & & 0.948 \\
\hline Majority smoke & 47 & 1.12 & 0.57 & 2.20 & 0.744 \\
\hline Do not know/not stated & 109 & 1.00 & 0.64 & 1.59 & 0.985 \\
\hline \multicolumn{6}{|l|}{ Sibling smoking } \\
\hline No siblings smoke & 810 & 1.00 & & & $<0.001$ \\
\hline Any siblings smoke & 132 & 2.22 & 1.48 & 3.32 & $<0.001$ \\
\hline Do not know/not stated & 28 & 2.23 & 1.02 & 4.88 & 0.044 \\
\hline \multicolumn{6}{|l|}{ Parental smoking } \\
\hline Neither parent smokes & 550 & 1.00 & & & 0.010 \\
\hline Either parent smokes & 362 & 2.05 & 1.15 & 3.67 & 0.015 \\
\hline Not sure/not stated/no mum/dad & 58 & 1.46 & 1.06 & 2.01 & 0.019 \\
\hline \multicolumn{6}{|l|}{ Block 2} \\
\hline \multicolumn{6}{|l|}{ Gender } \\
\hline Male & 501 & 1.00 & & & \\
\hline Female & 469 & 0.88 & 0.66 & 1.18 & 0.384 \\
\hline \multicolumn{6}{|l|}{ Socio-economic group } \\
\hline $\mathrm{ABC} 1$ & 447 & 1.00 & & & \\
\hline C2DE & 523 & 0.85 & 0.63 & 1.14 & 0.270 \\
\hline Age & 970 & 1.05 & 0.96 & 1.15 & 0.305 \\
\hline \multicolumn{6}{|l|}{ Block 3} \\
\hline \multicolumn{6}{|l|}{ Packaging receptivity to Silk Cut Superslims } \\
\hline Not receptive & 912 & 1.00 & & & \\
\hline Receptive & 58 & 4.42 & 2.50 & 7.81 & $<0.001$ \\
\hline \multirow[t]{2}{*}{ Model summary at each block } & \multicolumn{3}{|c|}{ Test of model coefficients } & \multirow{2}{*}{\multicolumn{2}{|c|}{ Nagelkerke R }} \\
\hline & & df & $\mathrm{p}$ Value & & \\
\hline Block 1 & 27.947 & 6 & $<0.001$ & & 0.041 \\
\hline Block 2 & 4.824 & 3 & 0.185 & & 0.048 \\
\hline Block 3 & 26.640 & 1 & $<0.001$ & & 0.085 \\
\hline Final model & 59.411 & 10 & $<0.001$ & & 0.085 \\
\hline
\end{tabular}

This is a cross-sectional study which depends on (albeit well validated) measures of future smoking intentions. There is a need, therefore, to follow-up young people over time to provide additional confirmation of the findings. Australia could provide a real-world context to further examine if exposure to plain packaging translates into reduced pack appeal and receptivity among adolescents, and whether the absence of regular and novelty packs leads to reduced susceptibility. That packaging design is driven by creative and technological industries provides a challenge for tobacco control. The tobacco industry is increasingly finding new ways to use the pack as a means of promoting the product. Within the pack, inlays and innerliners extend its promotional ability. ${ }^{50}$ Outside the pack, printed tear tapes, ${ }^{51}$ 'soft-look' and easy open films, ${ }^{52}$ and special coatings to produce 'surface-feel effects', 13 aim to enhance the tobacco brand experience. These developments should be monitored as this study has highlighted the relationship between positive evaluation of novelty packaging and adolescent smoking susceptibility.
Acknowledgements The authors would like to thank their late colleague Dr Lynn MacFadyen for her contribution to the development and design of the YTPS, and FACTS International for undertaking the fieldwork.

Contributors AF designed the data collection tools, analysed the data, and drafted and revised the paper. AF is the guarantor. AMM and GH devised the study. AMM designed the data collection tools and advised on the data analyses. GH, CM and AMM offered guidance on the initial drafting of the paper and helped revise the paper. SR conducted the GEE analysis and drafted these sections of the paper. All authors read and approved the final manuscript. All authors had access to and can take responsibility for the data and analysis.

Funding This work was supported by a grant from Cancer Research UK (C312/A8721). The UK Centre for Tobacco Control Studies contributed to the funding of Allison Ford and Gerard Hastings.

Competing interests None.

Ethics approval The study obtained ethics approval from the ethics committee of the Institute for Sociomanagement at the University of Stirling. Participants provided informed consent before participating.

Provenance and peer review Not commissioned; externally peer reviewed. Data sharing statement No additional data are available. 
Open Access This is an Open Access article distributed in accordance with the Creative Commons Attribution Non Commercial (CC BY-NC 3.0) license, which permits others to distribute, remix, adapt, build upon this work noncommercially, and license their derivative works on different terms, provided the original work is properly cited and the use is non-commercial. See: http:// creativecommons.org/licenses/by-nc/3.0/

\section{REFERENCES}

1. Pierce J, Choi WS, Gilpin EA, et al. Validation of susceptibility as a predictor of which adolescents take up smoking in the United States. Health Psychol 1996;15:355-61.

2. DiFranza JR, Wellman RJ, Sargent JD, et al. Tobacco promotion and the initiation of tobacco use: assessing the evidence for causality. Pediatrics 2006;117:e1237-48.

3. National Cancer Institute. Tobacco control monograph 19: the role of the media in promoting and reducing tobacco use. Bethesda, MD: National Cancer Institute, 2008.

4. Lovato C, Watts A, Stead LF. Impact of tobacco advertising and promotion on increasing adolescent smoking behaviours. Cochrane Database Syst Rev 2011;(10):CD003439.

5. Paynter J, Edwards R. The impact of tobacco promotion at the point of sale: a systematic review. Nicotine Tob Res 2009;11:322-8.

6. Mackintosh AM, Moodie C, Hastings G. The association between point-of-sale displays and youth smoking susceptibility. Nicotine Tob Res 2012;14:616-20.

7. Spanopoulos D, Britton J, McNeill A, et al. Tobacco display and brand communication at the point of sale: implications for adolescent smoking behaviour. Tob Control. Published Online First: 28 February 2013. doi: 10.1136/tobaccocontrol-2012-050765

8. Wakefield M, Morley C, Horan JK, et al. The cigarette pack as image: new evidence from tobacco industry documents. Tob Control 2002;11(Suppl 1):i73-80

9. Freeman B, Chapman S, Rimmer M. The case for plain packaging of tobacco products. Addiction 2008;103:580-90.

10. Moodie C, Hastings G. Making the pack the hero, tobacco industry response to marketing restrictions in the UK: Findings from a long-term audit. Int $J$ Ment Health Addict 2011;9:24-38.

11. Centre for Tobacco Control Research. The packaging of tobacco products. Stirling: Centre for Tobacco Control Research, University of Stirling, 2012.

12. Moodie C, Angus K, Ford A. The importance of cigarette packaging in a dark market: the 'Silk Cut' experience. Tob Control. Published Online First: 14 November 2012. doi: 10.1136/ tobaccocontrol-2012-050681

13. Glogan T. Tightening legislation in tobacco packaging_innovation blossoms! Tob J Int 2013. http://www.tobaccojournal.com/ Tightening legislation in tobacco packaging innovation blossoms.51660.0.html (accessed 3 May 2013).

14. Helk A. Appealing to all the senses. Tob J Int 2006. http://www. tobaccojournal.com/Appealing_to_all_the_senses.47923.0.html (accessed 3 May 2013).

15. Kotnowski K, Hammond D. The impact of cigarette pack shape size and opening: evidence from tobacco company documents. Addiction 2013;108:1658-68

16. M\&C Saatchi. Contact Report. M\&C Saatchi, 2000. http://www. tobaccopapers.com/PDFs/0500-0599/0533.pdf (accessed 3 May 2013)

17. Helk A. The last bastion of masculinity has fallen. Tob J Int 2007 http://www.tobaccojournal.com/The_last_bastion_of_masculinity has_fallen.48422.0.html (accessed 3 May 2013).

18. Perry CL. The tobacco industry and underage youth smoking: tobacco industry documents from the Minnesota litigation. Arch Pediatr Adolesc Med 1999;153:935-41.

19. Hastings GB, MacFadyen L. Keep smiling. No one's going to die: an analysis of internal documents from the tobacco industry's main UK advertising agencies. Centre for Tobacco Control Research and Tobacco Control Resource Centre. London: British Medical Association, 2000.

20. Cummings KM, Morley CP, Horan JK, et al. Marketing to America's youth: evidence from corporate documents. Tob Control 2002;11 (Suppl 1):i5-i17.

21. Department of Health. Consultation on standardised packaging of tobacco products. Department of Health, 2012. https://www.gov.uk/ government/uploads/system/uploads/attachment_data/file/170568/ dh_133575.pdf (accessed 3 May 2013)

22. Fuller E. Smoking, drinking and drug use among young people in England in 2011. London: NatCen Social Research, 2012.

23. DiFranza JR, Savageau JA, Fletcher K, et al. Measuring the loss of autonomy over nicotine use in adolescents: the DANDY
(Development and Assessment of Nicotine Dependence in Youths) study. Arch Pediatr Adolesc Med 2002;156:397-403.

24. Gervais A, O'Loughlin J, Meshefedjian G, et al. Milestones in the natural course of cigarette use onset in adolescents. Can Med Assoc J 2006;175:255-61.

25. Goldberg ME, Liefeld J, Kindra G, et al. When packages can't speak: possible impacts on plain and generic packaging of tobacco products. Ottawa: Health Canada; 1995, Expert Panel Report Prepared for Health Canada.

26. McCool J, Webb L, Cameron LD, et al. Graphic warning labels on plain cigarette packs: Will they make a difference to adolescents? Soc Sci Med 2012;74:1269-73.

27. Pechey R, Spiegelhalter D, Marteau TM. Impact of plain packaging of tobacco products on smoking in adults and children: and elicitation of international experts' estimates. BMC Public Health 2013;13:18.

28. Moodie C, Stead M, Bauld L, et al. Plain tobacco packaging: a systematic review. London: Public Health Research Consortium, 2012.

29. Centre for Health Promotion. Effects of plain packaging on the image of tobacco products among youth. Toronto: Centre for Health Promotion, University of Toronto, 1993.

30. Rootman I, Flay BR. A study on youth smoking: plain packaging, health warnings, event marketing and price reductions. Toronto: Centre for Health Promotion, University of Toronto, 1995.

31. Bondy SJ, Paglia A, Kaiserman MJ. Tobacco purchasing and marketing. In: Stephens T, Morin M. eds Youth smoking survey, 1994: Technical report. Ottawa: Minister of Supply and Services Canada, 1996:153-79.

32. Hammond D, Dockrell M, Arnott D, et al. Cigarette pack design and perceptions of risk among UK adults and youth. Eur J Public Health 2009;19:631-7.

33. Germain D, Wakefield MA, Durkin SJ. Adolescents' perceptions of cigarette brand image: does plain packaging make a difference? $J$ Adolesc Health 2010;46:385-92.

34. Moodie C, Ford A, Mackintosh AM, et al. Young people's perceptions of cigarette packaging and plain packaging: an online survey. Nicotine Tob Research 2012;14:98-105.

35. Beede P, Lawson R. The effect of plain packages on the perception of Cigarette health warnings. Public Health 1992;106:315-22.

36. Environics Research Group. Consumer research on the size of health warning messages - quantitative study of Canadian youth. Prepared for Health Canada. Toronto: Environics Research Group, 2008.

37. Gallopel-Morvan K, Moodie C, Hammond D, et al. Consumer perceptions of cigarette pack design in France: a comparison of regular, limited edition and plain packaging. Tob Control 2012;21:502-6.

38. Borland R, Savvas S, Sharkie F, et al. The impact of structural packaging design on young adult perceptions of tobacco products. Tob Control 2013;22:97-102.

39. Moodie C, Ford A. Young adult smokers' perceptions of cigarette pack innovation, pack colour and plain packaging. Australas Mark $J$ 2011;19:174-80.

40. Sparrow A. UK plans for plain cigarette packaging to be shelved. The Guardian 2013. http://www.guardian.co.uk/society/2013/jul/12/ plans-plain-cigarette-packaging-shelved? INTCMP=SRCH (accessed 12 July 2013).

41. Brown A, Moodie C. The influence of tobacco marketing on adolescent smoking intentions via normative beliefs. Health Educ Res 2009:24:721-33.

42. Moodie C, MacKintosh AM, Brown A, et al. The effect of tobacco marketing awareness on youth smoking susceptibility and perceived prevalence, before and after the introduction of a tobacco advertising ban. Eur J Public Health 2008;18:484-90.

43. Office for National Statistics. Table P01 2011 Census: usual resident population by single year of age and sex, England and Wales. Office for National Statistics, 2012. http://www.ons.gov.uk/ons/publications/ re-reference-tables.html?edition=tcm\%3A77-257414 (accessed 9 July 2013)

44. Zeger SL, Liang KY, Albert PS. Models for longitudinal data: a generalized estimating equation approach. Biometrics 1988;44:1049-60

45. Hammond D, Daniel S, White CM. The effect of cigarette branding and plain packaging on female youth in the United Kingdom. $J$ Adolesc Health 2013;52:151-7.

46. Philip Morris. Marketing new products in a restrictive environment. Philip Morris, 1990. Bates No. 2044762173/2364. http://legacy. library.ucsf.edu/tid/vra81c00 (accessed 7 May 2013).

47. Philip Morris. Opportunities in packaging innovation. Philip Morris, 1992. Bates No. 2048976191/6208. http://legacy.library.ucsf.edu/tid/ hwe36e00 (accessed 7 May 2013).

48. European Commission. Proposal for a directive of the European parliament and of the council on the approximation of 
the laws, regulations and administrative provisions of the member states concerning the manufacture, presentation and sale of tobacco and related products. Brussels: European Commission, 2012.

49. European Parliament Environment, Public Health and Food Safety Committee. Public Health Committee MEPs toughen up plans to deter young people from smoking. European Parliament, 2013. http://www.europarl.europa.eu/sides/getDoc.do?pubRef=- \%2f\%2fEP $\% 2 f \% 2 f T E X T \% 2 b I M-P R E S S \% 2 b 20130708 I P R 16824 \% 2 b 0 \% 2 b D O C$ $\% 2 b X M L \% 2 b V 0 \% 2 f \% 2 f E N \&$ language=EN (accessed 9 Aug 2013).
50. McEwen W. From riches to rags? Tob J Int 2011. http://www. tobaccojournal.com/From_riches_to_rags.50411.0.html (accessed 16 May 2013)

51. McEwen W. New technologies drive tear tape opportunities. Tobacco Journal International, 2011. http://www.tobaccojournal.com/ New technologies_drive_tear_tape_opportunities.50668.0.htm (accessed 16 May 2013).

52. Glogan T. Seeing the trends in brands. Tob J Int 2010. http://www. tobaccojournal.com/Seeing the trends in the brands.49866.0.htm (accessed 16 May 2013). 


\section{Correction}

Ford A, MacKintosh AM, Moodie C, et al. Cigarette pack design and adolescent smoking susceptibility: a crosssectional survey. BMJ Open 2013;3:e003282. In the 'Statistical analysis' section of this article, the occurrence of ' $>.44$ ' should have been ' $>.4$ '. The corrected sentence is as follows:

'Principal components were extracted using varimax rotation with the criteria of eigenvalues greater than 1, consideration of the scree plot and component loadings $>.4$.'

We apologise for this error.

BMJ Open 2013;3:e003282corr1. doi:10.1136/bmjopen-2013-003282corr1 